\title{
VIEWPOINTS
}

\section{What Makes a Muslim Leader}

\author{
Mohammad Hashim Kamali*
}

'Leadership Challenges for the New Era' was the subject of a plenary session at the 6th World Islamic Economic Forum (WIEF) which was held at the Kuala Lumpur Convention Centre (KLCC) between 18 and 20 May 2010 and in which the writer of these lines participated. The topic generated a lively discussion by a panel of eminent speakers.

HE Surin Pitsuan, Secretary General of ASEAN, for instance, moderated and referred in his opening remarks to the qur'ānic phrase $\bar{u} l \bar{l}$ 'l-amr ('those in charge of affairs'; 4:59), raising the question as to who are the $\bar{u} l \bar{l}$ ' $l$-amr of today who can usher us into the new era. The first panellist, Malaysia's former Prime Minister and Patron of IAIS Malaysia - Tun Abdullah Badawi - rightly stressed the role of education and recounted a question he was asked, during his recent visit to the Middle East, as to how Malaysia managed to be a success story among Muslim countries. He responded that Malaysia allocated a large portion of its budget to education - an area where Malaysia set a record. He also spoke passionately on the importance of grounding our youth in good values. The former Prime Minister of Pakistan, Shaukat Aziz, emphasised incorruptibility and transparency. He referred to several of the prevailing global problems - financial crises, terrorism, climate change, to name only a few - which are evidently the results of bad decisions, and thus a shortage of good leaders. Dr Ahmad Muhammad Ali, President of the Islamic Development Bank (IDB), recommended the 'bottom-up' approach to leadership whereby leaders arise from the grassroots level, as opposed to the elite-based 'top-down' model.

The moderator addressed the floor with a remark as to why the youth were preoccupied with qualifications and career matters and uninvolved in public affairs - only to invoke an energetic rebuttal from many younger speakers: the younger generation everywhere is crying for attention; they want to be involved, but their voices all too often fall on deaf ears. According to them, mostly it is the leaders who are not opening up.

* Professor Mohammad Hashim Kamali is the Chairman and CEO of IAIS Malaysia. An earlier version of this Viewpoint appeared on 31 May 2010 in The New Straits Times (Kuala Lumpur). 
In my own brief intervention, I explored the Islamic dimension of our discussion a little further, which I should like to elaborate in the following. Surin Pitsuan's quotation was reminiscent of another qur'ānic guideline: “Their (the Muslims') affair is a matter of consultation among them" (42:38). Consultative leadership as such entails engagement, communication, and partnership, which is also implying that leaders are connected, interactive, and maintain good relations with their grassroots. Furthermore, wal̄ al-amr (sing. of $\bar{u} l \bar{l}$ ' l-amr) is generic and inclusive and thus including anyone in charge of community affairs. A company director, judge, member of parliament, minister and head of state - all of them qualify in principle. This view, in turn, has been adopted into the juristic usage of the term wilāyah (pl. wilāyāt) to signify public authority. All government authorities are thus known as wilāyāt. Walī - lit. a friend and protector - is what a Muslim leader should be. He must remain open to sincere advice (nașinhah) and constructive criticism (mu 'äradah). In a renowned hadīth we read: "Every one of you is a custodian and responsible for what is in his custody" - this means that the ruler is responsible for what is in his custody and so is every man and every woman. The Prophet also instructed: "Be not weak in character nor simply do what others do, whether good or bad. Rather make up your own minds: you may follow others in good deeds but not when they do something wrong." What we see then is open and accessible leadership - not of a single person, but one in which everyone can take charge of what is placed under his or her custody. The Prophet also praised a leader who empathised with his people, reaching out to them and aligned with them around their needs and interests, and denounced leaders who distance themselves from the grassroots. Humility and dedication to service run through Islam's guidelines on leadership, as in the hadith: "The leader of a people is (veritably) their servant." The second caliph, 'Umar b. al-Khațāa (d. 644), added his voice to say: "There is no pomp and ceremony in Islam." Leaders must also listen. Thus when someone rudely criticised 'Umar in the presence of senior Companions, one of them asked for permission to deal with the intruder, but the caliph responded: "No, let him speak. No good will come out of us if we did not listen." In saying this, however, this writer admits that Islamic history is littered with despotic leadership and grave neglect of basic guidelines.

Moreover, age too is not a determining factor of leadership. 'Alī b. Abī Ṭālib (d. 661), who later became the fourth caliph of early Islam, was the youngest among the Companions, but he was also a leading voice and a very close assistant of the Prophet. Similarly, when the Prophet appointed the 18-year-old Usāmah b. Zayd to lead an army expedition, elder Companions acceded, and events showed he was a good choice. Gender too should also not be a hindrance, as there is no prohibitive injunction on it. However, at times, certain issues arose that were mainly to medieval society practices. The Prophet's wife, 'A' 'ishah bt. Abī Bakr (d. 678), was a learned 
and leading figure among Companions, and later caliph 'Umar appointed a woman, Shifā' bt. 'Abd Allāh (d. 665), as market inspector of Medina. The only exception Muslim scholars have made is for the head of state, as he would be the commanderin-chief of the armed forces. However, subsequent material changes in warfare and leadership make it inadvisable for the head of state to lead the army in person.

Al-Māwardī (d. 1058), the author of a renowned text on governance, enumerates several qualities of a good leader, which he summarises into three: knowledge ('ilm), just character ('adālah), and wisdom (hikmah). Leadership arises from knowledge, insight and virtue, a vision of the good, courage, humility, commitment, and God-consciousness. These are the ingredients of hikmah in a good leader. Knowledgeable leaders exuberate clarity of purpose and persuasiveness. The Qur'ān thus instructed the Prophet: "Take not a stand on something you are not knowledgeable about" (17:36). The term firāsah (foresight), a synonym of hikmah, is often used in the context of siyassah shar 'iyyah (judicious policy), which affords the leader flexibility in the management of public affairs in order to make effective decisions in emergencies and fast unfolding scenarios. For instance, when calamity strikes and looters take people's properties, the leader must act, and not, as it were, to await legal technicalities of evidence and proof.

Siyāsah shar 'iyyah thus combines political acumen with the higher purposes of the shari ${ }^{\prime} a h$. It is premised on the recognition that policy measures and administrative action by government leaders may go beyond the stricter confines of a certain ruling of the sharì $a h$ in the wider interests of good governance and justice. 